\title{
Comprehensive Integration in Smart Factories of the Future
}

\author{
Jozef Kováč ${ }^{1}$, Peter Malega ${ }^{1, *}$, Juraj Kováč ${ }^{2}$ \\ 'Institute of Management, Industrial and Digital Engineering, Park Komenského 9, Košice, Slovakia \\ 2 Department of Robotics, Park Komenského 8, Košice, Slovakia
}

\begin{abstract}
The vision of a highly flexible, especially automated, customer-adapted production that forms the basis for the futuristic intelligent factory concept requires innovative solutions that allow vertical and horizontal integration of realized production but also non-production processes and their realization production systems. The goal is horizontal and vertical integration, as well as integrated digital integration of engineering throughout the value chain of production the final product and necessary services.
\end{abstract}

Keywords: Integrated designing; innovative designing; production systems; production system models; intelligent technical systems; cyber-physical systems; intelligent production; Industry 4.0; integration level; CIM OSA

\section{Introduction}

Increasing production digitization and virtualization, creating a network of automated plants and businesses (and other trends) lead to significant changes in existing industrial and production chains. In the industry and especially in the production, the real world and the virtual world are becoming more and more integrated. The proportion of advanced industrial automation is increasing, not only in the production, but also in all spheres of human activity. [1, 5]

Predicted changes in the industry and in the production of the future (fourth industrial revolution, intelligent industrial systems, Internet of Things, Internet of Services, etc.) are also a challenge for producers of production machinery and equipment, hardware and software suppliers, communication and connection technology producers and others. $[3,18]$

Solving a number of technical, technological, organizational, environmental and social problems requires a high level of integration. Factories of the future will need to tackle and integrate a comprehensive problem structure that is comprehensive. $[2,19]$

\section{System Approach - Significant Characteristics of Intelligent Production Projects}

Future intelligent production will have significant system support. It will use in an integrated form the production, information - communication; network and software technologies implemented in new intelligent production systems (Fig. 1). Methodological approaches to ensuring the development of production are now widely utilized by system teaching and rules to identify and optimize existing and to design new production systems and their clusters.

System approach in general is the exploration and modelling of an object involving its decomposition into elementary parts and examines them from the 
point of view of functional action and integration into the system structure.

From the aspects of structure homogeneity we can distinguish four basic types of systems [5]:

\section{n standard,}

- well-structured,

nstructured,

\section{- unstructured.}

All systems can be further characterized as simple, compound and complex.

Simple or determined are systems whose architecture and function are based on the utilization of well-known physical, technological and other relations, also described by deterministic instruments.

In classical mechanical engineering, systems consist of a large number of homogeneous elements classified into a few classification grades. There are relatively simple relationships between the elements. Systems are characterized as simple or complex and there are examine a set of elements as a whole. Relations of functional behaviour of complex systems can be thoroughly examined and mathematically described.
The basis of the complex systems, to which intelligent production belongs, is presented in system theory. Important attributes of the complex intelligent system are [6, 9]:

- functional operation of the system is dependent on the surrounding environment,

- purposiveness of the complex system is focused on one or a set of challenging goals,

- there is a permanent change of internal processes in the system and their stabilization is necessary,

- the principle of adaptability is based on sensing of process variability in the system and stabilizing of processes,

- processes in the system have information character, have a certain degree of novelty and unpredictability, which is presented as the transmission and exchange of information within the system and in the linkage of the environment, - many complex systems haven 't got sharpness, - complex systems are basically unique.

Development of complex systems results in intelligent systems with linkage to the environment, and the ability to scan information from the environment, process these information and to create the plan and programs of their activities. [10]

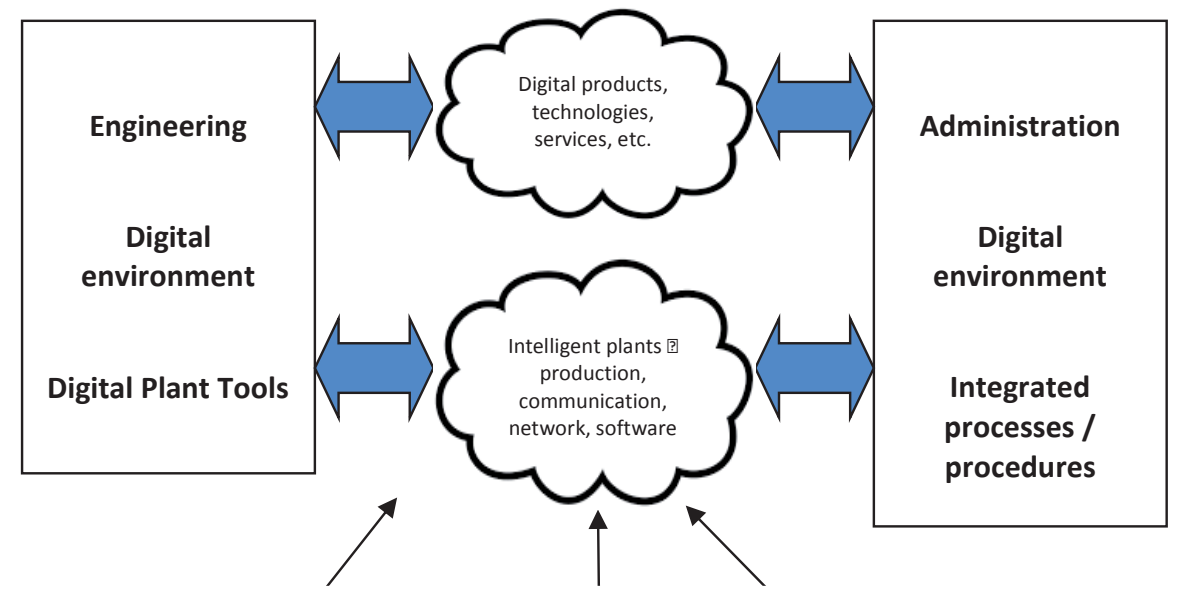

Global information and communication system - real time
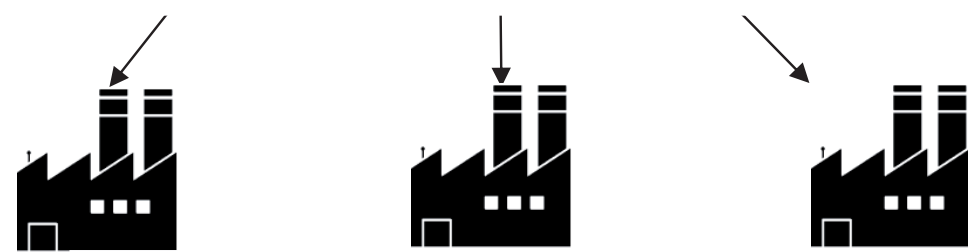

Flexible/changeable/reconfigurable production systems high-productive production technologies

Fig. 1: Future intelligent production [21]. 
Recognition of simple, complex and intelligent systems is also the problem. The simplest way is to use algorithms for this purpose. In algorithms of operation of simple systems are integrated only powerful blocks, in complex systems also decision blocks. Intelligent systems characterize decision trees.

In the process of intelligent production creation is important the analysis of characteristics of stability, controllability and reliability. Stability of production systems work is a condition of economic effects. Simple systems (production technique without managerial systems) have passive forms of stability: durability (work without failures, long life-cycle) and balance (regular, rhythmic activity).

Active forms of stability are reliability and flexibility. The most important expression of stability is reliability - it maintains the structural balance of system functions.

Functional behaviour of the system over a long-time period of time characterizes the ability to survive in different situations. It consists in significant rate in adapting to new conditions. Production systems are most often adapted to product changes

Flexibility of production systems characterizes the system's ability to take various types of production objects from the environment and quickly adapt to their production its own activity. The behaviour of systems is often judged by their evident and potential efficiency [7, 12]:

\section{- Evident efficiency characterizes synergic quality effects} that are based on gaining a higher effect, such as a simple sum of the effects of structure subsystems.

- Potential efficiency gains new quality of the system by changing its structure. The main restriction governing the increase in the potential effectiveness of the system results from its interaction with the environment. The resulting failures are expressed by probability of information misrepresentation.

The interaction of the system and the environment has stochastic character with probability of changing the input (u) and output (v). Characteristic $\mathbf{P}(\mathbf{u}, \mathbf{v})$ determines the system efficiency. It performs the system objective (A).

Probability can be expressed as:

$$
P(u, v)=P(A)
$$

It characterizes the realization of the system objectives and is the potential system efficiency. For complex systems, efficiency can be expressed in the form of:

$P(u, v)=\left\{\begin{array}{l}0, \text { if } v>v_{0} \\ 1, \text { if } v<v_{0}\end{array}\right.$

The concept of system feasibility is formulated from the probability $\mathbf{P ( t )}$ of realizing the objective $\mathbf{A}$ of the system at time $\mathbf{t}$. When the probability $\mathbf{P}_{\mathbf{o}}$ and

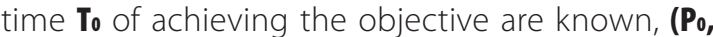
$\left.\mathbf{T}_{\mathbf{0}}\right)$ are parameters of feasibility. The system is real, if

$P(T) \geq P_{0}$ and $T \leq T_{0}$

In the process of intelligent production systems creation, it is necessary to examine the environment conformity. The compensation characteristic is determined. These aspects are important if the production system $\mathbf{A}$ needs to get help $V$ for its operation in the environment $\mathbf{B}$. Required help $\mathbf{V}$ can be expresses as a function

$V=V(u, A, B)$

Compensation characteristic represents function:

$$
£(A, B)
$$

Function also shows, whether the system by its determination will acquire the legitimacy of existence in relation to the environment. Compensatory characteristic allows qualitative evaluation of many conditions and changes of lower intelligence level to higher lower intelligence level. [11]

Real production systems typically don't have ideal system properties and behaviour. Because of that fact it is necessary to optimize these systems. Great importance has optimization on the principle of a priori methods that lead to creation of models and identifications. Systems, in which excessive effort is made, to recovery them, are usually depreciated. Systems, in which the recovery isn't complete, are a major financial burden. [14]

\section{Integration in the Intelligent Production Designing}

In the introduction of intelligent production, it is important carefully integration in the new 
production systems with other new or existing subsystems. For example, when company introducing a flexible production system; it is necessary to solve problems related with the transport system of tools and production objects, configuration of the managerial system and the qualification of operators - their knowledge and skills. Important areas are [13]:

\section{- information and communication system,}

\section{- system of people,}

\section{own production system.}

These areas must be designed and implemented in a uniform way, which will provide the necessary benefits. Total integration generally increases the benefits. Therefore, in many places, the philosophy of automation from and "a to $z$ " is in the centre of attention. But in practice is recommended selected step-by-step approach. They respect existing technologies in production areas, and integration is accepted as a factor that combines components as a function carrier and maximizes benefits. Developmental sign is a movement from automation of islands and production cells to larger complexes or networks. [15]

Very important factor is to start integration in time. Significant cooperation between suppliers and users is important. System architects (integrators) point out timely contacts between users and suppliers, and the understanding of the possibilities.
Intelligent production requires integrated expertise. It depends on good and timely preparation, and also on conceptual and detailed processing. System integrator can be a strong person or project organization. Understanding this term may vary, for example [16]:

system integrator performs the function of two or more machine cells fusion and the function of computer control systems,

asystem integration is a solution of dialectical contradictions between suppliers and users of modern technique,

astem integration is a task not only to install the system, but also to optimally operate with it.

For intelligent production area is important concept, which includes:

- Innovation: selection of innovative project methods, selection of intelligent devices, computers, creation of production cells, etc.,

-Integration: development of the complete concept of production systems and alternative subsystems, configuration of the complete system and its design,

- Implementation: preparation, picking and installation of equipment, design of plant and start of production.

Aspects of intelligent integrated production systems are shown in Fig. 2.

System integration allows creating concepts of future plants. Unsuccessful projects are also the result of non-compliance of the integration principles. The problem arises from an inherent

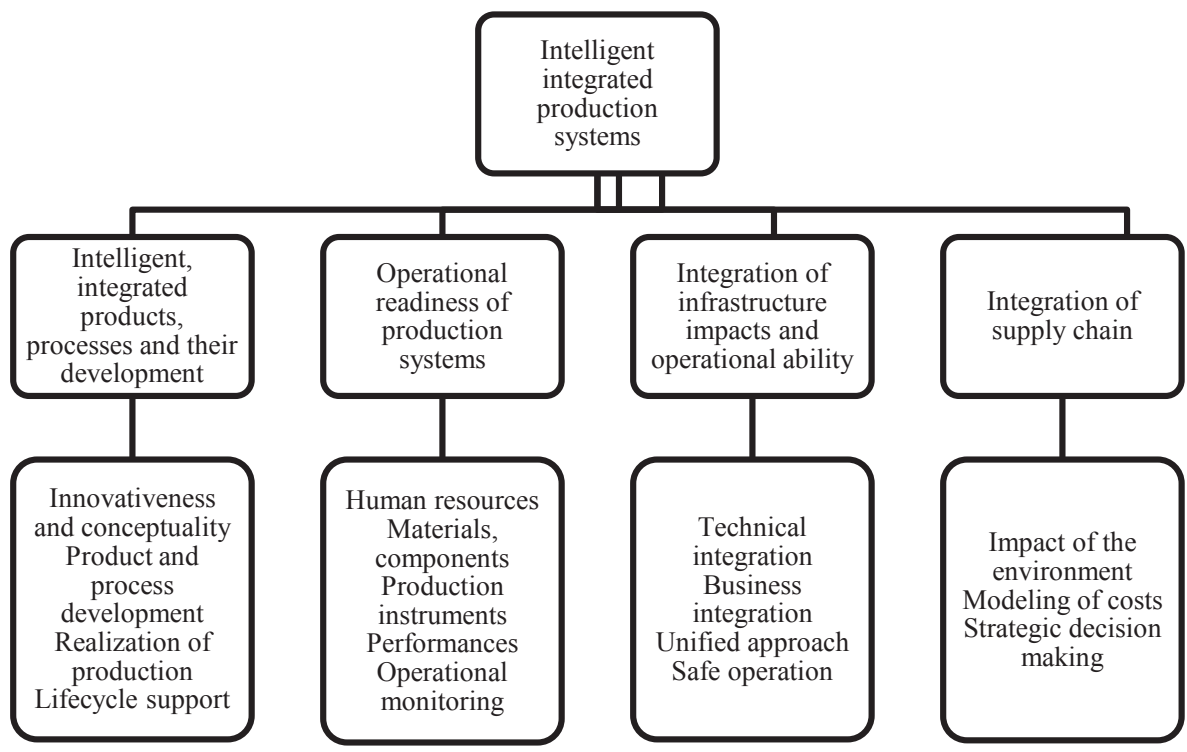

Fig. 2: Aspects of intelligent integrated production systems. 
flow that is interrupted with separation of the concept into two parts:

\section{- Project, \\ - Installation.}

Two-step understanding causes difficulties in preparation and picking processes, and often results in the selection of multiple suppliers unrelated to each other.

In general, the integrated system is the system, which is linked with permanent links. Functions are in the integrated system synchronized.

Tab. 1: Levels of integration [19].

\begin{tabular}{|c|c|}
\hline Level & Characteristic \\
\hline Physical integration & $\begin{array}{l}\text { Till now more physical solutions of integration have been implemented (production } \\
\text { centre, production cell, production line and others). Attention now is focused on com- } \\
\text { munication that develops as an integrated system at the level of production areas and } \\
\text { in engineering office. }\end{array}$ \\
\hline Data integration & $\begin{array}{l}\text { At this level it is data integration. Creating of data basis is the role that must be sol- } \\
\text { ved, if we speak about production integration. General presentation of data for human } \\
\text { is language, for machine it is a description of data.Dictionary is actually an instrument } \\
\text { of data integration in the data basis. Data integration requires uniform description for } \\
\text { specific application. }\end{array}$ \\
\hline Scheduling integration & $\begin{array}{l}\text { In each system, all activities are realized at time intervals, and because of that fact are } \\
\text { scheduled. In production, the scheduling of operations and work is the core of all acti- } \\
\text { vities. Material delivery systems and material flows are particularly important. }\end{array}$ \\
\hline Function integration & $\begin{array}{l}\text { Rules and procedures are a tool for integrating functions and determining which func- } \\
\text { tions have to be performed, by whom and in what way. Uniform rules ensure that the } \\
\text { functions are performed easily, without duplicate efforts. Activity rules are an essential } \\
\text { integration element and their importance is vertical and horizontal. }\end{array}$ \\
\hline $\begin{array}{l}\text { Integration of attitudes and be- } \\
\text { haviour }\end{array}$ & $\begin{array}{l}\text { Attitudes that the organization is interested in characterize ethics and are the result of } \\
\text { the uniform principles application. This is about the attitudes and behaviour that sys- } \\
\text { tem applies inside and in relation to the environment. This level is formed in the pro- } \\
\text { duction integration as a socio-technical system. }\end{array}$ \\
\hline Integration of principles & $\begin{array}{l}\text { This aspect is related to socio-technical systems. In terms of intelligent production are } \\
\text { important aspects such as respect of personality, supply of only quality products, pro- } \\
\text { vision of best services, and so on. }\end{array}$ \\
\hline Integration of benefits & $\begin{array}{l}\text { Utility of the production organization determines partial and global goals in perfor- } \\
\text { ming all functions and activities throughout the organization. Social utility acts as the } \\
\text { decisive factor in all decisions. Activities that are not in accordance with collective inte- } \\
\text { rests should be recognized and eliminated in time. }\end{array}$ \\
\hline
\end{tabular}

production, assembly, material handling, packaging, purchasing, quality management, production management, inventory and processing management, maintenance and distribution.

In the vertical development hierarchy are included also production preparation functions.

The term integration includes the
Interconnection of elements in the system is physical, through technical equipment, or includes also information flows through computer and humans.

The term production also includes production preparation system, efficient production system, auxiliary and distribution activities and their links to the environment. All direct and also indirect production activities are included in the concept of integration as main and supporting.

Integration develops horizontally and vertically. Horizontal development includes the preparation of semi-finished products, the components interconnection and coordination of the linking functions for physical components and information throughout the production network. The scope of integration requires interconnection of production facilities, but in particular production systems and production preparation. Full integration also includes suppliers and customers, i.e. the whole value chain. 
In general, seven levels of integration can be modelled (Tab. 1).

It is important to recognize integration from interconnection (interface solutions), although they are often regarded as equivalent solutions.

Integration also significantly influences the production organization. It should be taken into account that not all elements can be integrated with another. Integration is a physical phenomenon and its realization depends on the substantive nature of the elements. All elements can't be integrated, but they can be interconnected through interface. This can be fully applied to the production structures. Integration is not one status, but it develops in stages. Systems also have the partial integration. It is realized at different levels and there are many levels for this purpose. Observer determines the fact, if the systems are integrated or not. [18]

Integration depends largely on computers utilization as integrating function executors. The integration of information subsystems is essential, and integrated production is achieved without the production automation. In this case, human work is more intensive, which means that the computer intensifies outputs from production, through human labour.

\section{Creating standards for Integration}

European standard CIM OSA (Open System Architecture for CIM is standard that was created for process-based business modelling, monitoring, and management of activities.

Integration of business activities is primarily realized by the utilization of information and communication technologies [4].

CIM OSA is a general reference model that through its elements and methods, provides solutions for enterprise focused on integration of individual subsystems. Description of a special reference model is realized through three other models [6]:

\section{- business,}

\section{- implementation,}

\section{- middle (internal) model.}

The structure of each CIM OSA model analyses the approach method based on the functional, informational, source and organizational view.

The CIM OSA structure visualisation is the cube, which is characterized by full sets of models and reference architecture. Different levels support different views on the business model. [7, 9]

Integrated business processes model CIM OSA is shown in Fig. 3.

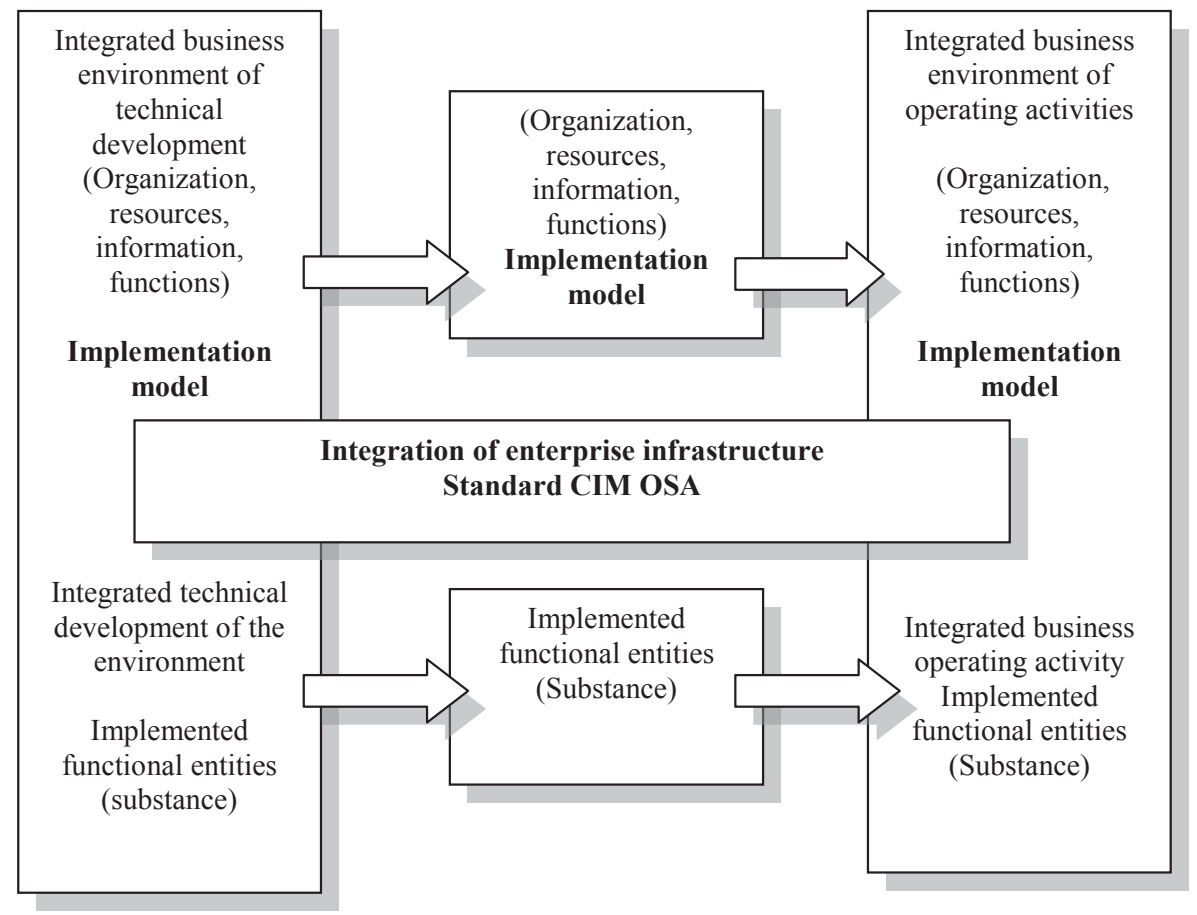

Fig. 3: Integrated business processes model CIM OSA [20]. 
A new approach to integration is defined in platform Industry 4.0. RAMI 4.0 (Reference Architectural Model Industrie 4.0) - Fig. 4 contains three levels. In the model, individual functions of Industry 4.0 can be divided into classes and further developed. In the three-dimensional space there are described all basic aspects of Industry 4.0. Complex linkages are decomposed into smaller and simpler substructures, and are developed independently.

The right horizontal axis contains hierarchical levels according to international standard IEC 62264 - Integrated Enterprise Management System. Hierarchical levels represent the various functions performed in plants and production systems. Functions are defined in the sequence from the creation of "product" to the Internet of things and services, "e.g. Connected World".

The left horizontal axis defines the life cycle of devices and products. The basis is IEC $62890-$ Product and System Lifecycle Management used for measurement, management and automation in the process industry. The classes are defined as [11]:

\section{-type,}

\section{- instance.}

The type is the instance when the product is developed, testing of the prototype is completed, and serial production has started.

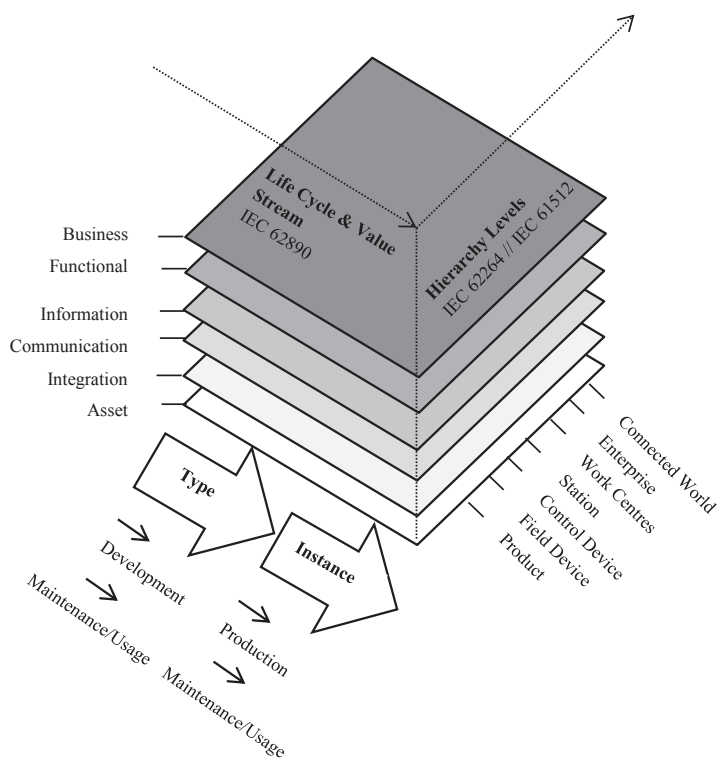

Fig. 4: Reference Architecture Model Industrie 4.0 [22].
Industrie 4.0 component is a model that describes the real entity of the production process (e.g. sensor, actuator to plant), product or all IP of the business. Industrie 4.0 component is implemented with the help of "Administration Shell". It is a 3D model of a real object and there are the data, its properties, created during the production process.

Data within Administration Shell are continuously stored and updated in the enterprise database and available throughout the product life cycle. Fig. 5 characterizes the Industrie 4.0 Component.

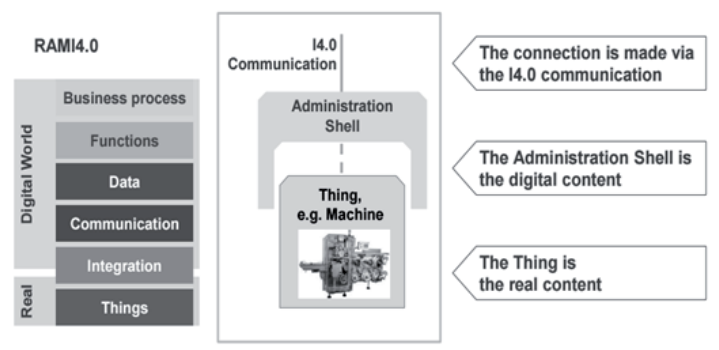

Fig. 5: Industrie 4.0 Component [22].

\section{Conclusions}

The concepts of system integration will be constantly redesigned and will have to be implemented in the Factory of the future. Their development should be stimulated by building relevant knowledge bases that will bring together knowledge and implementation experiences with a strong support of information, communication and intelligent network technologies. The knowledge and ideas in the contribution want to point to the importance of solving this specified problem.

\section{Acknowledgments}

This article was created by implementation of the project VEGA 1/0853/16 New project technologies for the creation and implementation of future factories.

\section{References}

[1] Bracht, U., Geckler, D., Wenzel, S.: Digitale Fabrik - Methoden und Praxisbeispiele. Springer, 2011. ISBN 978-3-540-890386

[2] Buda, J., Kováč, M.: Design and operation of robotic systems. Alfa Bratislava, 1990, ISBN 80-05-00680-2

[3] Cyber - Physical Systems. Innovationsmotor für Mobilität, Gesundheit, Energie und Produktion. Acatech - Deutsche Akademie der Technikwissenschaften, 2011, www.springer- 
link.com

[4] DIN SPEC 91345 Referenz architektur modell Industrie 4.0 (RAMI4.0)

[5] Geisberger, E., Broy M.: Integrierte Forschungsagenda Cyber-Physical Systems. Acatech studie, Heidelberg Springer Verlag, 2012

[6] Groover, M., P.: Automation, Production Systems and Computer - Integrated manufacturing. Second Edition. Printice Hall International, Inc., 2001, ISBN 0-13-089546-6

[7] Hankel, M.: Industrie 4.0: The Reference Architectural Model Industrie 4.0 (RAMI 4.0). ZVEI, Frankfurt am Main, 2015

[8] Kersten, W., Koller, H., Lödding, H.: Industrie 4.0. Wie intelligente Vernetzung und kognitive Systeme unsere Arbeit verändern. GITO mbH Verlag Berlin, 2014. ISBN 978-395545-083-0

[9] Kováč, M., Buda, J., Šimšík, D.: Designing of production systems. Alfa Bratislava, 1991. ISBN 80-05-00709-4

[10] Kováč, M., Kováč, J.: Innovative design of production processes and systems. Košice : TU-SjF, 2011. ISBN 978-80-5530805-0

[11] Kováč, J., Mihok, J.: Industrial engineering. Edition of scientific and professional literature. SjF TU v Košiciach, 2013. ISBN 978-80-553-0806-7

[12] Kováč, J., Rudy, V., Kováč, Juraj: Production automation. Edition of scientific and professional literature. SjF TU v Košiciach, 2016. ISBN 978-80-553-2311-4

[13] Kováč, J.: Factories of the futurre. In.: Trends and Innovative Approaches in Business Processes "2016", Vol. 19. pp.6, 2016. ISBN 978-80-553-3018-1

[14] Kühn, W.: Digitale Fabrik. Fabriksimulation für Produktionsplaner. Carl Hanser Verlag München, Wien, 2006, ISBN-10: 3-446-40619-0, ISBN-13: 978-3-446-40619-3

[15] Madarász, L., Bučko, M., Andoga, R.: Integration aspects of the creation and operation of CIM systems. Elfa Košice, 2006, ISBN 80-8086-043-2, EAN 978808086043

[16] Scheer, A., W.: CIM Computer Integrated Manufacturing. Towards the Factory of the Future. Third, Revised and Enlarged Edition. Springer-Verlag, Berlin Heidelberg, 1994, ISBN-13: 978-3-642-78990-6, e-ISBN-13: 978-3-642-78988-5

[17] Siciliano, B., Khatib, O.: Handbook of Robotics. Springer Verlag Berlin Heidelberg, 2016. ISBN 978-3-319-32550-7, e-ISBN 978-3-319-32552-1[18] Information taken from the catalogues of Metalchem Toruń and LyondellBasell Industries.

[18] Šeminský, J.: Brief Introduction to the Refrrencie Architecture model for Industrie 4.0. In.: Trends and Innovative Approaches in Business Processes "2016 6", Vol. 19. pp.6, 2016. ISBN 978-80-553-3018-1

[19] VDINDE-Gesellschaft Mess-und Automatisierungstechnik. Status Report: Reference Architecture Model Industrie 4.0
(RAMI4.0) (Vol. 0). (2015). http://www.zvei.org/Downloads/ Automation/5305

[20] http://www.acatech.de

[21] http://www.manufuture.org

[22] http://industrie40.vdma.org/

\section{Biographical notes}

Jozef Kováč, prof. Ing. CSc.: is professor an also a head of Institute of Management, Industrial and Digital Engineering. His professional activities are oriented on the analysis and development of new methods and practices of integrated design of production systems and testing of design solutions.

Peter Malega, Ing. PhD.: is assistant professor and also a member of Institute of Management, Industrial and Digital Engineering. His professional area of activity is oriented on economic effectiveness, competitiveness, productivity and strategic and innovation management.

Juraj Kováč, Ing. PhD.: is assistant professor and also a member of Department of Robotics. He deals with the activities like the realization of the laboratory system, creating of physical and virtual models of production systems, experimental verification of the virtual reality principles. 